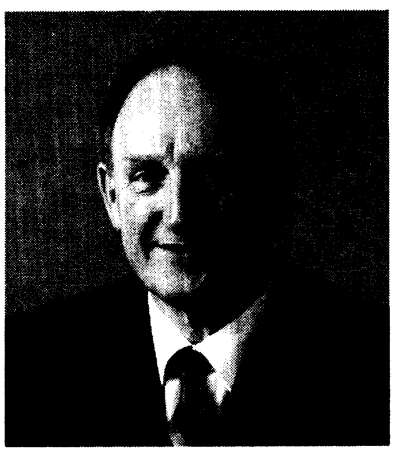

\section{We Are Indeed International}

As your editor, I continue to be impressed by the national and international status of Optical Engineering. In my earlier editorials I have indicated in some detail the origin of the papers published in Optical Engineering. However, during the SPIE Orlando meeting I was asked what percentage of non-U.S. papers we were publishing these days-well, here is the answer plus a little historical background.

Table 1 shows the data for the last six years (Volumes 27 through 32). From 1988 to 1993 the number of papers published increased by $143 \%$; the number of U.S. papers increased by $63 \%$ while the non-U.S. papers increased by $268 \%$. As can be seen from the table, the percentage of non-U.S. papers has now reached $59 \%$. For completeness in the table, I have also listed the number of countries that contribute to the journal, and that too is up significantly. I am, of course, conscious of the fact that special sections can play a role in these numbers. For example, in 1988 the January issue contained a special section on optics in the United Kingdom. In 1993, there was a special section on Asia, and Canada and Hungary were also covered. One of these days when I get a little time I will analyze the trend without these special sections.

The international nature of Optical Engineering raises some special issues. Since papers come from around the world, then so must the reviewers. This adds a significant cost to our operations since international mail and other couriers are rather expensive. We must also deal with the uncertainties of international mail, although I am pleased to note that this is currently a minor problem. Occasionally, I get one or two sheets of a paper and the remains of an envelope all wrapped in plastic with a notification that it was damaged in transit. My favorite is the one shown in Fig. 1. It was just part of an envelope and nothing else-but it arrived in its plastic bag! Language is another issue. Our copy editors have to work overtime on some papers to get them into an acceptable style.

I get some charming letters such as the following:

Dear Professor:

I sent this letter to you together with my manuscript which I want to submit to you and hope it can be published on Optical Engineering -- the word famous scientific Journal. I will be glad to revise it if the manuscript is not as sandard as to be acceptable. I will also apreciate your help no matter this manuscript can be published or not. It's no doubt that I will learn and benefit a lots from you and your colleagues by our exchange.

Thank you for your precious time and hope to hear from you.
Table 1 Comparison of U.S. versus non-U.S. papers.

\begin{tabular}{cccccc}
\hline Year & Total & U.S. & Non-U.S. & \% Non-U.S. & NumberofCountries \\
1993 & 423 & 173 & 250 & 59.1 & 33 \\
1992 & 330 & 155 & 175 & 53.0 & 24 \\
1991 & 238 & 169 & 69 & 29.0 & 27 \\
1990 & 200 & 153 & 47 & 23.5 & 17 \\
1989 & 187 & 132 & 55 & 29.4 & 21 \\
1988 & 174 & 106 & 68 & 39.1 & 19 \\
\hline
\end{tabular}

$$
\begin{aligned}
& \text { AN J. THOMPSON, } \\
& \text { OPTICAL ENGINEERING, } \\
& \text { UNT HOPE AVENUE, } \\
& \text { ITER, } \\
& \text { IRK 14620, } \\
& \text { A. }
\end{aligned}
$$

Fig. 1 Fortunately, an atypical address label.

And I get some rather disturbing ones such as the following postscript:

P.S. Our letters are very often intercepted by some unscrupulous people in the department. We, therefore, request you kindly to use the below mentioned address for all future correspondence which is the residential address of the principal author.

In any event, we are proud to serve the international community in optical science and engineering.

\section{Editor's Anecdote}

Since I have been talking about the mail my anecdote will relate to that subject on this occasion. My brother in England wanted to send me a journal that he thought would interest me. He obviously gave instructions to someone else to send me a copy. The envelope arrived handwritten and addressed to:

Provost Mr. B.J. Thompson

(Mr. T's Brother)

692 Mount Hope Avenue

Rochester, NY 14627 USA 
July 1994

Adaptive Wavelet Transforms

Harold H. Szu

U.S. Navy

Naval Surface Warfare Center

Code R44

10901 New Hampshire Avenue

Silver Springs, MD 20903-5000

301/394-3097 • 301/394-3923 FAX

\section{August 1994}

Digital Image Recovery and Synthesis

Paul S. Idell

Rockwell International

Rocketdyne Division

MS SS46

P.O. Box 7922

Canoga Park, CA 91309-7922

818/586-8238 • 818/586-5295 FAX

E-mail: pidell@windance.rdyne.rockwell.com

September 1994

Optics in South Africa

Hannes Markusse

ELOPTRO

Institute of Atomic Physics

P.O. Box 869

Kempton Park 1620, South Africa

Maurice W. McDowell

CSIR/Production Technology Div.

Productiontek

P.O. Box 395

Pretoria 0001, South Africa

$27128413418 \cdot 27128412131$ FAX

\section{October 1994}

Optics in Russia

V. Ya. Panchenko

Scientific Research Center for Technological Lasers

Russia Academy of Sciences

B-333, Gubkina, 3

117971 Moscow, Russia

E-mail: ilc@ compnet.npimsu.msk.su

(095)135-54-30 • (095)334-02-01 FAX

November 1994

Micro-Optics

Chandrasekhar Roychoudhuri

University of Connecticut at Storrs

Photonics Research Center

MS-157, Room 312

260 Glenbrook Road

Storrs, CT 06269-3157

203/486-4816 • 203/486-3789 FAX

December 1994

Optics in Ireland

John Hegarty

University of Dublin

Trinity College

Department of Pure and Applied Physics

Dublin 2, Ireland

+353-1-7022019 • +353-1-711759 FAX

Conleth D. Hussey

University of Limerick

Lightwave Technology Research Ctr.
Plassey Pk.

Limerick, Ireland

$35261333644 \cdot 35261330316$ FAX

January 1995

X-Ray/EUV Optics

Richard B. Hoover

NASA Marshall Space Flight Center

ES52 Space Science Center

Huntsville, AL 35812-0001

E-mail: hoover@ssl.msfc.nasa.gov

205/544-7617 • 205/544-5856 FAX

February 1995

High Heat Flux Optical Engineering

Ali M. Khounsary

Argonne National Laboratory

Advanced Photon Source, APS 362

Argonne, IL 60439

708/252-3384 - 708/252-3222 FAX

Manuscripts due July 1, 1994.

March 1995

Optical Engineering in Ophthalmology

Suganda Jutamulia

Kowa Company, Ltd.

Silicon Valley Office

100 Homeland Court, Suite 302

San Jose, CA 95112

408/441-9300 • 408/441-0537 FAX

Toshimitsu Asakura

Hokkaido University

Research Institute for Electronic Science

Sapporo, 060 Japan

81-11-716-2111 • 81-11-758-3173 FAX

Manuscripts due Aug. 1, 1994.

April 1995

Optics in the Ukraine

Oleg V. Angelsky

Chernovtsy University

Department of Correlation Optics

2 Kosyubinsky Street

274012 Chernovtsy

Ukraine

(03722) 44730 • (03722) 41314 FAX

Manuscripts due Aug. 15, 1994

July 1995

Optics in Switzerland

P. K. Rastogi

Swiss Federal Institute of Technology-Lausanne

Laboratory of Stress Analysis

CH-1015 Lausanne

Switzerland

E-mail: rastogi@elgc.epfl.ch

(021) $6932445 \cdot(021) 6934748$ FAX

Manuscripts due Nov. 15, 1994

\section{September 1995}

Optical Science \& Engineering in Finland

Seppo Honkanen

Nokia Research Center

P.O. Box 45

FIN-00211 Helsinki

Finland

$+35804376470 \cdot+35804552557$ FAX

Manuscripts due Jan. 15, 1995
November 1995

Optical Remote Sensing and Image Processing

Mohammad A. Karim

Bradley D. Duncan

University of Dayton

Center for Electro-Optics

300 College Park

Dayton, OH 45469-0227

513/229-2241 • 513/229-3177

513/229-2471 FAX

Manuscripts due April 1, 1995

December 1995

Optics in Polymer Science and Technology

Maksymilian Pluta

Institute of Applied Optics

Kamionkowska 18

03-805 Warsaw, Poland

(4822) $184405 \cdot$ (4822) $133265 \mathrm{FAX}$

Andrzej Wasiak

Institute of Fundamental Technological Research

Polish Academy of Sciences

Savietokrzyska 21

00-012 Warsaw, Poland

(4822) 269815 FAX

Manuscripts due April 1, 1995.

January 1996

Optical Science and Engineering in Argentina

Guillermo H. Kaufmann

Universidad Nacional de Rosario

Instituto de Fisica Rosario

Applied Optics Group

Bv. 27 de Febrero 210 bis

2000 Rosario

Argentina

E-mail: guille@ifir.edu.ar

or gkaufman@arosario.bitnet

5441825838 • 5441257164 FAX

Manuscripts due June 1, 1995

Visual Communications and Image Processing

Cheng-Tie Chen

Bellcore, NVC 3X-321

331 Newman Springs Road

Red Bank, NJ 07701

908/758-3106 • 908/758-4371 FAX

E-mail: ctc@ nyquist.bellcore.com

Kou-Hu Tzou

COMSAT Laboratories

22300 Comsat Drive

Clarksburg, MD 20871

301/428-4663 • 301/428-9287 FAX

E-mail: kouhu@ctd.comsat.com

Ya-Qin Zhang

GTE Laboratories

40 Sylvan Road

Waltham, MA 02254

617/466-2259 • 617/890-9320 FAX

E-mail: yz00@gte.com

Manuscripts due June 1, 1995 